PNL-SA--20267

DE92 015254

\title{
EVALUATION OF WASTEWATER TREATMENT REQUIREMENTS FOR THERMOCHEMICAL BIOMASS LIQUEFACTION
}

D. C. Elliott

May 1992

UNO 1992

Presented at the

International Energy Agency Advances in

Thermochemical Biomass Conversion

May 11-15, 1992

Interlaken, Switzerland

Work supported by

the U.S. Department of Energy

under Contract DE-AC06-76RLO 1830

Pacific Northwest Laboratory

Richland, Washington 99352

\section{DISCLAIMER}

This report was prepared as an account of work sponsored by an agency of the United States Government. Neither the United States Government nor any agency thereof, nor any of their eniployees, makes any warranty, express or implied, or assumes any legal liability or responsibility for the accuracy, completeness, or usefulness of any information, apparatus, product, process disclosed, or represents that its use would not infringe privately owned rights. Reference herein to any specific commercial product, process, or service by trade name, tradernark manufacturer, or otherwise does not necessarily constitute or imply its endorsement, recom mendation, or favoring by the United States Government or any agency thereof. The views and opinions of authors expressed herein do not necessarily state or reflect those of the United States Government or any gaency thereon.

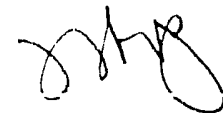




\title{
EVALUATION OF WASTEWATER TREATMENT REQUIREMENTS FOR THERMOCHEMICAL BIOMASS LIQUEFACTION
}

\author{
DOUF" is C. ELLIOTT \\ Pacific Northwest Laboratory* \\ P. O. Box 999 \\ Richland, WA 99352 \\ U.S.A.
}

\begin{abstract}
The broad range of processing conditions involved in direct biomass liquefaction lead to a variety of product properties. The aqueous byproduct streams have received limited analysis because priority has been placed on analysis of the complex organic liquid product. The range of organic contaminants carried in the aqueous byproducts directly correlates with the quantity and quality of contaminants in the liquid oil product. The data in the literature gives a general indication of the types and amounts of components expected in biomass liquefaction wastewater; however, the data is insufficient to prepare a general model that predicts the wastewater composition from any given liquefaction process. Such a model would be useful in predicting the amount of water that would be soluble in a given oil and the level of dissolved water at which a second aqueous-rich phase would separate from the oil. Both biological and thermochemical processes have been proposed for wastewater treatment, but no treatment process has been tested. Aerobic and anaerobic biological systems as well as oxidative and catalytic reforming thermochemical systems should be considered.
\end{abstract}

\section{INTRODUCTION}

Biomass resources can provide a substantial energy resource. Liquids are preferred for use as transportation fuels because of their high energy density and handling ease and safety. Liquid fuel production from biomass can be accomplished by any of several different processes including hydrolysis and fermentation of the carbohydrates to alcohol fuels, thermal gasification and synthesis of alcohol or hydrocarbon fuels, cirect extraction of biologically produced hydrocarbons such as seed oils or algae lipids, or direct thermochemical conversion of the biomass to liquids and catalytic up- 
grading to hydrocarbon fuels. This report is limited to a discussion of direct thermochemical conversion to achieve biomass liquefaction and the requirements for wastewater treatment inherent in such processing.

\section{DIRECT THERMAL PROCESSING OF BIOMASS TO LIQUIDS}

\section{Thermochemical Liquefaction of Biomass}

Direct liquefaction of biomass by thermochemical means has been studied continuously as a process for fuel production for the past twenty years. Modern development of the process can be traced to the early work at the Bureau of Mines as an extension of coal liquefaction rest:arch [1] and to the work on municipal solid waste at the Worcester Polytechnical Institute [2]. Ongoing work at universities and national laboratories in the U.S., Canada, Scandinavia, and other European countries has resulted in much progress since the mid-1970s [3]. Currently the research has focused on two general processing configurations, high-pressure liquefaction and flash pyrolysis.

High-pressure liquefaction: This type of processing, shown conceptually in Figure 1, has been studied at a number of sites around the world and includes a number of process variations [4]. The processing temperature is generally in the range of $350 \mathrm{C}$ with operating pressures in excess of 1000 psig. The feedstock is generally fed as a slurry, and the nature of the slurry vehicle is a major variable in the studies. The presence of added reducing gas or catalyst is an important variable. Most studies show that the operation in the presence of alkali facilitates the formation of liquids with lower oxygen contents. Product recovery is also a major issue and is highly dependent on the slurry vehicle. Various systems of centrifugation, distillation, and solvent fractionation have been tested.

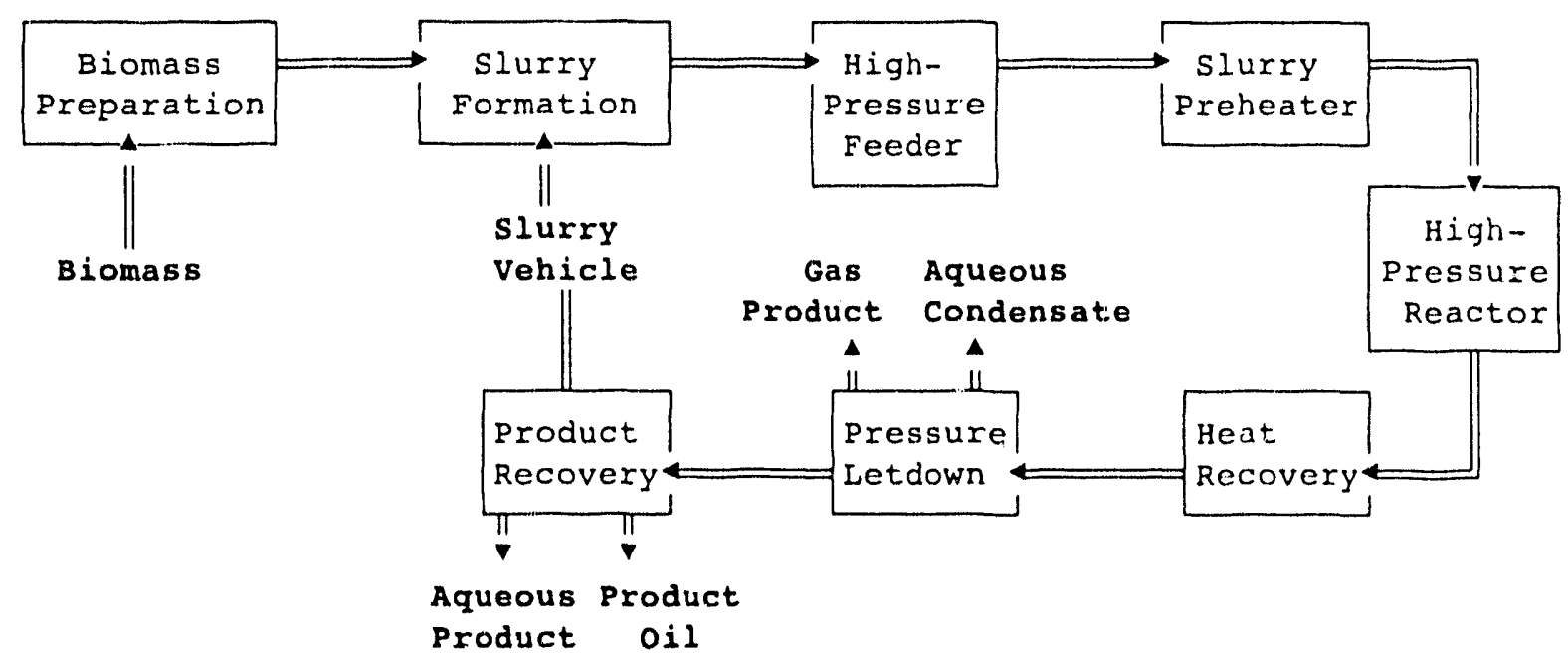

FIGURE 1. Conceptual high-pressure liquefaction process

Flash pyrolysis: This concept, shown in Figure 2, has also been widely studied [5], [ó]. Miodern engineering methods have optimized the yieid of liquid 
product through control of feedstock particle size, residence time, processing pressure, and processing temperature. The flash concept varies from the older technology of pyrolysis in which the biomass was slowly heated, thus it produces lesser amounts of volatile gases and condensible vapors and more solid char product [7]. Current atmospheric pressure process development utilizes short residence time, $<1$ second, in isothermal, fluidized- or entrained-bed reactors. The feedstock is carried by an inert gas carrier into the reactor where it thermally decomposes to tar vapors, water vapor, gases, and char solids. Various systems for vapor quench and recovery have used complicated condensing and coalescing systems including electrostatic precipitators, cyclones, filters, and/or spray towers. Another type of flash pyrolysis system operates at subatmospheric pressure to keep the vapor residence time to a minimum while controlling the rate of temperature increase in larger particle biomass feedstock [8].

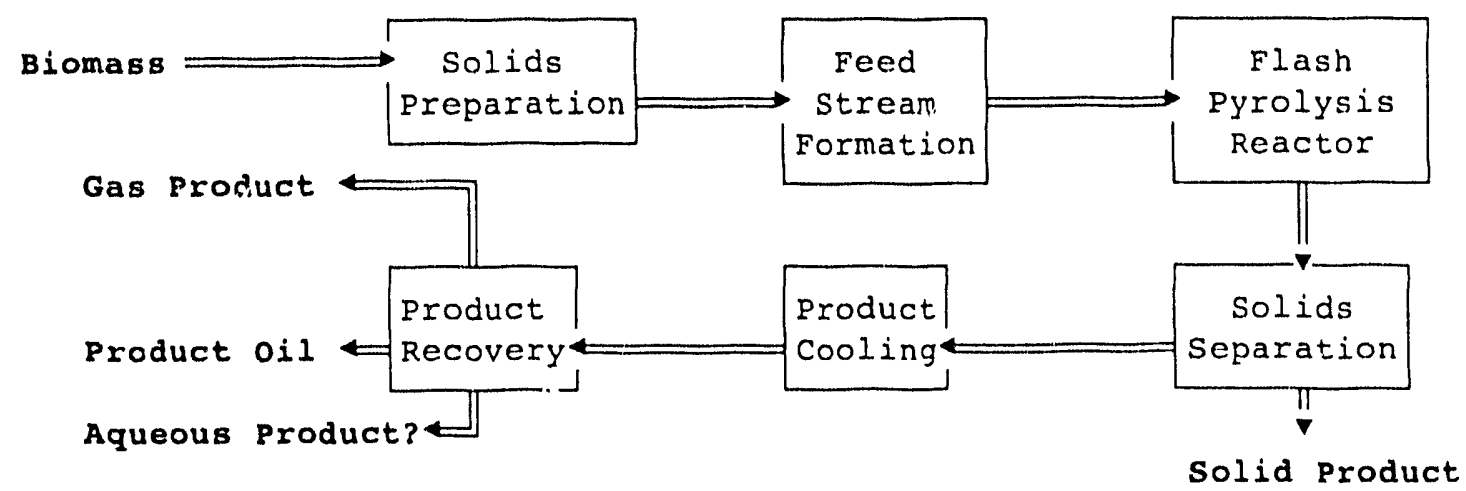

FIGURE 2. Conceptual flash pyrolysis process

The products from the high-pressure liquefaction and atmospheric flash pyrolysis processes are quite different from each other. The properties of the two products are summarized in Table 1. The high-pressure product is a viscous, phenolic oil. Its physical properties of high viscosity, high boiling point, and limited water solubility are readily understood as resulting from the oxygenated and aromatic character of the product components. Because the water solubility is limited, there is a separate aqueous product stream, which is usually recovered both from the condensed lizuid product and also from the cooled gas product after pressure letdown.

The flash pyrolyzate is much more oxygenated and is more water soluble. The more oxygenated components in the product, acids and aldehydes/ethers, cause it to be more corrosive and more thermally unstable, respectively. As a result of the high level of dissolved water in the product, the flash pyrolyzate is much less viscous. In addition, the amount of aqueous phase byproduct is greatly reduced or eliminated entirely in most cases. However, the normal operation of vacuum pyrolysis, with staged condensation of the product, and slow pyrolysis, with extended reaction time, result in a separate aqueous byproduct stream in both cases. This effect is discussed more completely later in this report. 
TABLE 1

Typical properties of raw products from direct liquefaction of biomass [9]

\begin{tabular}{lcc}
\hline & $\begin{array}{c}\text { High-Pressure } \\
\text { Liquefaction }\end{array}$ & $\begin{array}{c}\text { Flash } \\
\text { Pyrolysis }\end{array}$ \\
\hline Elemental Analysis (wet) & 72.6 & \\
Carbon, wt \% & 8.0 & 43.5 \\
Hydrogen, wt\% & 16.3 & 7.3 \\
Oxygen, wt\% & $<45$ & 49.2 \\
Sulfur, ppm & 1.21 & 29 \\
H/C atom ratio (dry) & 1.15 & 1.23 \\
Density, g/ml & 5.1 & 1.23 \\
Moisture, wt\% & 15,340 & 24.8 \\
HHV, Btu/lb & $15,000 @ 61 \mathrm{C}$ & 9,710 \\
Viscosity, cps & & $59 @ 40 \mathrm{C}$ \\
Distillation Range & $8 \%$ & $44 \%$ \\
IBP-225C & $32 \%$ & coked \\
225C-350C & $7 \%$ &
\end{tabular}

\section{Upgrading biomass-derived liquids}

Because of the chemical differences in the two products described above, different upgrading schemes have been derived for converting the products into usable hydrocarbon fuels. Catalytic hydroprocessing is an obvious choice based on the existing knowledge of sulfur removal from petroleum products. Catalytic hydrodeoxygenation of the products has been studied in several laboratories [10]. Developments in further product refinement by catalytic cracking and hydrocracking have also been presented [11]. This type of processing is most directly applicable to the high-pressure liquefaction products; however, a process has been identified which allows the use of catalytic hydroprocessing of the thermally unstable pyrolyzate product [12]. A refinement of this process is the use of a nonisothermal catalyst bed, which eliminates the intermediate step of product cooling and separation of a contaminated aqueous phase byproduct [13].

Another alternative, which has been used successfully with the pyrolyzate products, is the catalytic cracking of the vapors over a zeolite catalyst without the intermediate quenching and recovery of the tars [14]. The process requires 7 bed of zeolite to crack the tar vapors to lighter components, including gasoline range hydrocarbons, and separates much of the oxygen in the pyrolysis oil as carbon oxide gases and water vapor. Byproducts from the cracking include fuel gas and coke, which can be burned to heat the process, and olefin gases, which can be reacted with the gasoline to increase the yield and octane rating. An important step in the process is the incineration of a water stream containing much of the unconverted pyrolysis material. Zeolite catalyst processing has the advantage of directly treating the 
pyrolysis vapors without condensing and allowing separation of an aqueous phase until after the oil components are hydrophobic and more easily recoverable from the water.

\section{PROCESS WASTEWATERFROM LIQUID FUELS PRODUCTION}

Biomass liquefaction technology has had a relatively short developmental life. As a result, the limited amount of product analysis undertaken thus far has emphasized the oil phase material with much less analysis of the byproduct water phase. For example [15], the extensive central analytical program undertaken in Canada in support of their biomass liquefaction program included only one aqueous sample in a slate of 62 different product samples.

\section{Direct thermochemical liquefaction}

High-pressure liquefaction: Contamination of the byproduct water stream from high-pressure biomass liquefaction was recognized early on in the technology development. The earliest Bureau of Mines report on the CO-Steam process utilization with municipal waste indicated that the aqueous phase carried considerable organic material that could be converted to separable oil product by recycle in the process [16]. No details of analysis of the water phase was reported, although organic contaminants were described as acids.

Later development of the process in the Biomass Liquefaction Experimental Facility at Albany, Oregon, also provided little insight into the composition of the wastewater components. The single reference to water analysis is a list of components identified in the aqueous condensate stream as part of supporting research at Pacific Northwest Laboratory (PNL) [17]. The components listed are given below in Table 2 .

The concentration of the organic components can be significant. Limited analysis of the water phase in one test at the Albany Facility showed that TOC (total organic carbon) levels of 1 to $2 \%$ were produced in a liquefaction test using hydrolyzed wood chips at $10 \%$ solids concentration in water as the feedstock [18]. These dissolved components, effectively lost from the product yield, were reported to represent a significantly larger portion of the biomass liquefaction product than those lost to the water in operations with wood chips in oil as feedstock [19].

A related research effort at the Lawrence Berkeley Laboratory provides detailed analysis for the aqueous phase products from high-pressure liquefaction [20]. Their TOC analyses show levels of 1.6 to $3.6 \%$ in single-pass experiments; recycle concentrations reached $14.3 \%$ of TOC. The components are similar to those reported at PNL (see Table 2) with a much larger fraction of organic acids.

Based on titrations of the aqueous phases, the actual masses of acids and anions were determined. The weight percentages of these materials ranged from $1.3 \%$ to $3.3 \%$ in single-pass tests and up to $27.0 \mathrm{wt} \%$ in a multiple-recycle test. Estimated neutral organic concentrations in the aqueous phase from single pass tests ranged from $1.2 \%$ to $6.0 \%$ but remained at only $3.2 \%$ in the recycle test. Apparently, the acids and anions, being less volatile, tended to concentrate in the aqueous phase 
TABLE 2

Organic compounds identified in aqueous phase from high-pressure liquefaction

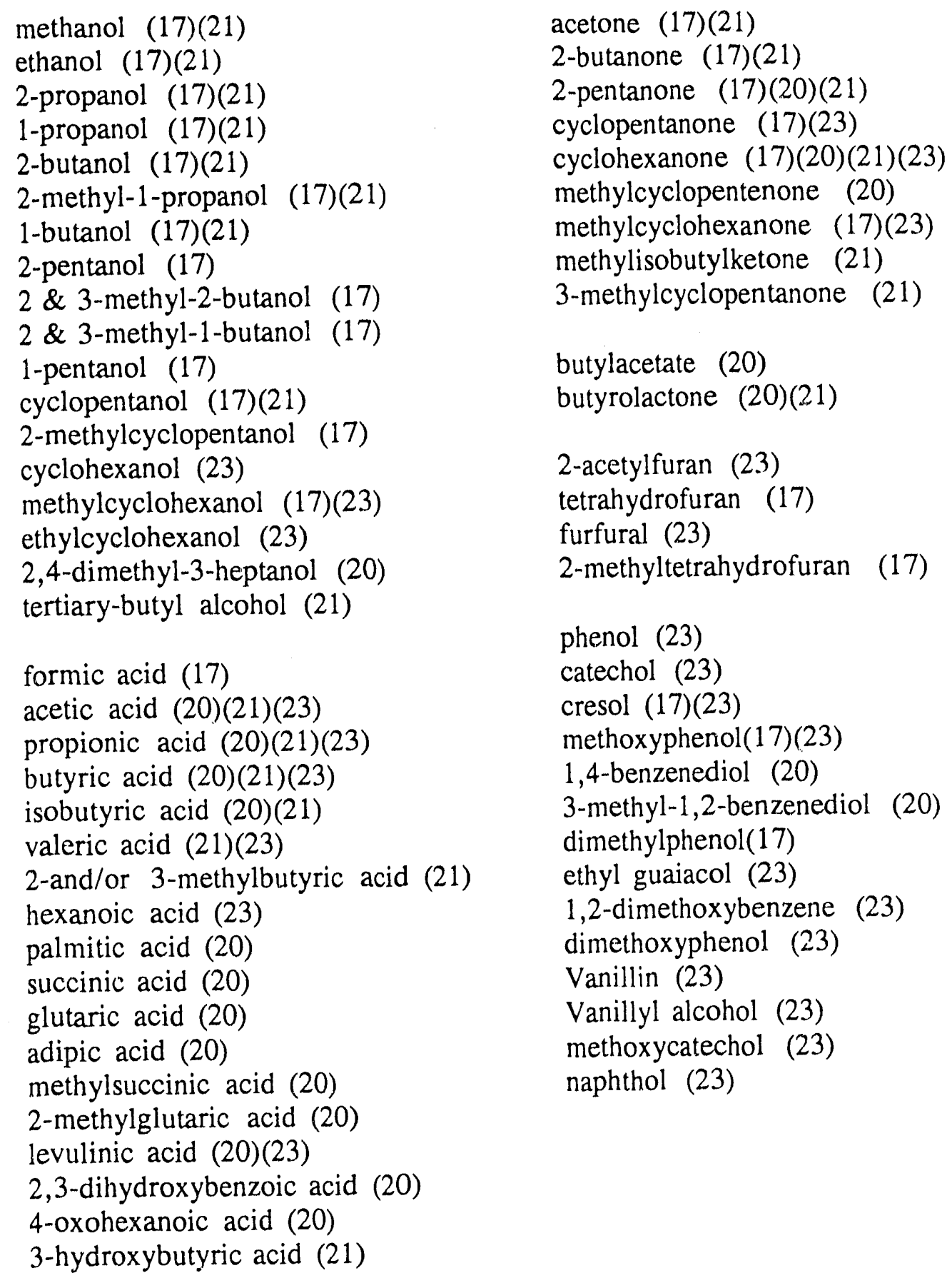

acetone $(17)(21)$

2-butanone (17)(21)

2-pentanone $(17)(20)(21)$

cyclopentanone (17)(23)

cyclohexanone $(17)(20)(21)(23)$

methylcyclopentenone (20)

methylcyclohexanone (17)(23)

methylisobutylketone (21)

3-methylcyclopentanone (21)

butylacetate (20)

butyrolactone (20)(21)

2-acetylfuran (2.3)

tetrahydrofuran (17)

furfural (23)

2-methyltetrahydrofuran (17)

reference numbers in parentheses

during recycle operations while the neutral components tended to flash overhead in the pressure letdown. The overhead aqueous condensate from the recycle test contained an estimated $6.7 \mathrm{wt} \%$ neuträi organics and only $0.43 \mathrm{wt} \%$ acids and anions. Other information that corroborates these results can be found in the literature from other hiomass liquefaction research efforts in Canada and Europe. One 
important paper from the University of Saskatchewan deals specifically with the aqueous byproducts from biomass liquefaction in a high-pressure water slurry. The paper reports that up to a third of the biomass is lost to the aqueous phase [21]. Separation of the aqueous phase components was undertaken and analysis of two of the phases is reported in detail. The components identified are found in the list in Table 2. In addition to the two phases described in detail, the paper also mentions that the other two fractions contain low molecular weight phenolics.

Research results from the University of Toronto provide additional input from a batch catalytic hydrogenation of wood in water and batch steam pyrolysis of wood. Both systems show significant loss of organic to the aqueous phase. In the hydrogenation, batchwise recycle of aqueous was tested with final concentrations reaching $40-50 \mathrm{~g} / \mathrm{L}$ TOC $(4-5 \%)$. This level of contamination represents about $18 \%$ of the wood feed ending up in the aqueous stream [22]. Aqueous recycle tests with the high-pressure steam pyrolysis gave similar results [23]. A single pass resulted in $20 \mathrm{~g} / \mathrm{L}$ TOC, which increased to $60 \mathrm{~g} / \mathrm{L}$ after two recycles. During the recycle process, the increase in organic contamination was found to result from additional acetic acid in the aqueous phase while phenolic content increased only slightly. Numerous chemical components were identified (see Table 2) and quantitative yield information is provided. The major component in the aqueous phase was acetic acid.

The aqueous phase from one test at Toronto was the single aqueous phase analyzed in the Canadian centralized analysis effort in support of biomass liquefaction [15]. The dilute nature of the sample (4\%-5\% TOC) made the proton NMR analysis nearly meaningless, but an extended time run on the carbon-13 NMR spectra showed a strong contribution from acetate ( $2.38 \%$ total acids by HPLC). Many other components were suggested by the numerous strong resonances in the spectra. No sugars were detected by normal silylation procedures on a GC.

From peat liquefaction tests at the Royal Institute of Technology in Stockholm, published results show high levels of water contamination by organics. In two experiments TOC is reported as 8.9 and $15.0 \mathrm{~g} / \mathrm{L}$. The yields of water and watersolubles are lumped together with losses in the data, so the yield of water soluble organics from peat is probably less than the reported amount, $18 \%$ to $26 \%$ of carbon [24].

Flash pyrolysis: One perceived advantage of flash py'rolysis systems for the production of liquid fuels from biomass is the absence of a byproduct aqueous stream with the inherent loss of organic product. The highly oxygenated (hydrophilic) oil components produced in flash pyrolysis allow more complete solubilization of the water into the oil product. As a result, all the leading flash pyrolysis process developers claim a stable single-phase product with no wastewater stream (see reference 5). In effect, the wastewater stream is dissolved in the oil product and is included in the product stream. If the oil is used as turbine fuel, the wastewater is effectively incinerated with the oil product.

Lack of an aqueous phase is limited to operations with highly oxygenated biomass forms. Experiments with flash pyrolysis of peat [25] or municipal waste components (particularly plastics) [26] resulted in two phase products. The peat aqueous product has been analyzed to show $11.4 \mathrm{wt} \%$ carbon loading made up of a number of some oxygenates and anhydrosugars (see Table 3). These are the same ccimponents reported for cellulose and wood pyrolysis studies [27]. 
TABLE 3

Aqueous phase components from flash pyrolysis

Formic Acid

Acetic Acid

Formaldehyde

Glyoxal

Hydroxyacetaldehyde

Acetol

Ethylene Glycol

Methanol
Cellobiosan

Levoglucosan

Glucose

Fructose

Glyceraldehyde

Methylglyoxal

Aqueous phase separation can be forced even with wood flash pyrolysis oils. If steam is used as the carrier in the pyrolysis reactor, a second aqueous phase is more likely to be produced. The effect is similar to that reported with the addition of water (to levels $>25 \%$ ) to flash pyrolysis oil to separate it into aqueous and tar phases [28]. Such a procedure has been used to recover the chemicals which preferentially separate from the tar into the aqueous phase (see reference 6).

A more general consideration of pyrolysis of biomass would include the older slow pyrolysis systems, which produce more char and less oil. Because of more severe processing conditions (higher temperature, longer residence time), the oil products from these systems contain less chemically bound oxygen and are less hydrophilic. As a result, there is usually a two-phase liquid product: a less dense pyrolysis water phase that is highly contaminated with organics and a heavy tar phase that also contains a significant amount of dissolved water. If this oil product is used as boiler fuel, the wastewater stream is usually co-fired with the oil in the boiler.

Another variation of the flash pyrolysis system is the vacuum pyrolysis system being developed in Canada. This multiple-hearth reactor was envisioned as a useful fractionating system for the pyrolyzate oil. If chemicals are the product of the process, then the separation is useful; if boiler fuel is the product from the process, then the fractionation achieved may be less useful. Typical operations of the vacuum pyrolysis system result in a primary oil product and a secondary condensate product which is a highly contaminated byproduct water [29]. The organic content of the secondary condensate is reported to range from $45 \%$ to $55 \%$, but process improvements (primarily in cooler design) are projected to lower the level to $10 \%$ to $20 \%$. The characterization of the carboxylic acids in the aqueous phase has also been reported [30].

\section{Process wastewater from upgrading biomass oils}

Hydroprocessing operations: Upgrading biomass oils by hydroprocessing can lead to fewer water treatment requirements. The hydroprocessing reacts hydrogen gas with the oils to remove oxygen and make them more volatile. Both of these changes make the oil less water soluble, resulting in cleaner byproduct water streams. The more complete the hydroprocessing, the less contaminated the byproduct water. Unpublished data from our own research at PNL on hydrotreating high-pressure biomass liquefaction oils shows that the carbon level in the byproduct water from hydrotreating operations is generally around $0.1 \%$ to $0.2 \mathrm{wt} \%$ when the product 
gasoline contains less than $1 \%$ oxygen. As less oxygen is removed from the oil, more oil is left dissolved in the water, i.e.1\% carbon in water@2.5\% oxygen in oil and $2 \%$ carbon in water@5.5\% oxygen in oil. The dissolved components were assumed to be oxygenated remnants of the biomass oil.

For the case of hydroprocessing pyrolysis oils, the single-step, nonisothermal procedure was developed, at least in part, to eliminate the wastewater treatment problem resulting from separating the aqueous condensate following the lowtemperature hydroprocessing stabilization step. The recovered wastewater following low-temperature hydroprocessing is highly contaminated with up to $17 \mathrm{wt} \%$ carbon having been measured. Separation and loss of this macerial is detrimental to the process. By proceeding with the single-step upgrading which produces a gasoline hydrocarbon product, the loss of feed carbon to the wastewater was much lower, $0.6 \%$ to $1.0 \%$ carbon in the water for products containing $0.8 \%$ to $1.5 \%$ oxygen (see reference 12 ). Intermediate levels of processing the pyrolyzates results in increased levels of wastewater contamination similar to the high-pressure oil processing. The numbers from PNL unpublished data range from $5 \%$ carbon in the water with a $16 \%$ oxygen content oil to $17 \%$ carbon dissolved in the water with a $34 \%$ oxygen content oil. As mentioned above, the dissolved components were assumed to be oxygenated remnants of the biomass oil.

Catalytic-cracking operations: An advantage of the catalytic processing of the pyrolysis vapors is the elimination of the condensation step and potential for water phase separation. By processing the primary vapors immediately to the fuel components, the condensed product is a hydrophobic hydrocarbon rather than an oxygenated oil. Little information is available on the specifics of this product and the condensate streams. Most of the descriptive information suggests that all the aqueous condensate streams will be incinerated in the conceptual process.

An inherent quality of the cracking process is its less specific mechanism. Some of the primary pyrolysis product is deemed to be unreactive on the zeolite catalyst. This material, mostly phenolic, is expected to be concentrated in the aqueous byproduct and incinerated in the conceptual process. Other pyrolysis components will be reacted to coke on the catalyst and will be burned in a catalyst regeneration step. As a result, the process developers envision no wastewater treatment will be necessary.

\section{IDENTIFICATION OF ENVIRONMENTAL, SAFETY AND HEALTH CRITERIA}

In general, the statutes and regulations discussed in this paper (from the U.S.A.) protect human health and the environment by regulating discharges to the groundwater, surface water, and soil. To do so, the regulations contain performance and design standards and criteria that must be met by plant operators. Permits may also be required; these permits prescribe the specific performance and design criteria that must be met to satisfy the regulatory standards. Some permits authorize discharges of substances to the environment, while others are required before waste management and other facilities are allowed to operate. The permits for a facility may be issued by several regulatory agencies, such as the federal government's Environmental Protection Agency (EPA), state departments of ecology or social and 
health services, or local agencies, such as county health districts, city sewer systems, or pollution control authorities.

There are several overlaps in the process. The federal Congress enacted environmental pollution control statutes that direct EPA to promulgate implementing regulations. These statutes may also direct or authorize the states to develop regulatory programs. As a result, the states can develop both "flowdown" statutes, which restate or are more stringent than the federal regulations, and "nonflowdown" statutes, which are regulations encompassing areas not covered by the federal regulations. All of these regulations are subject to continual updating, which usually tightens the restrictions. In addition, Department of Energy (DOE) operations are subject to DOE orders that cover wastewater handling.

The procedure for obtaining permits to build and operate a biomass liquefaction plant will include a careful review of all the appropriate environmental regulations. First a Notice of Intent to file an environmental assessment will be given to EPA. The subsequent assessment will be made to determine whether a full-scale Environmental Impact Statement (EIS) must be prepared or if a Finding of No Significant Impact can be made. The Assessment will include preliminary evaluation of environmental impacts of the proposed project including effects on public health and welfare, archeological impacts historical values, endangered species concerns, property values, as well as need to governmental permits. The EIS is a more detailed evaluation of all these issues as well as evaluation of alternatives to the preferred project plañ. Preparation of each of these documents includes public input periods and governmental review.

This discussion is written from a U.S. federal government point of view as a reasonable baseline for consideration at this point in the development of biomass liquefaction. However, some states (Washington, for example) have implemented even more strict pollution control measures as they are allowed under the federal legislation. Therefore, the specific site of the biomass liquefaction plant will determine the exact level of pollution control required. In addition, these regulations seem to be subject to continual change which almost always leads to tighter control. As a result, when the biomass liquefaction plant is built, the level of pollution control required will almost certainly be more stringent than it is now.

It is important to note that the release specifications described below apply to both normal operations and off-normal operations. That is, releases of any type over the set limits can result in fines and other legal retribution, whether the releases were purposeful or accidental. Therefore, plant design should take into account releases of all types. Maintenance procedures as well, especially equipment cleanout, need to be considered in the plant design. Aliowance must be made for collection of all waste streams from the plant, including off-spec startup products, spent maintenance materials, and feedstock storage pile runoff.

\section{U.S. statutes and regulations that may be applicable}

Resource Conservation and Recovery Act of 1976 (RCRA): RCRA piovides for "cradle-to-grave" regulation of the generation, transportation, storage, treatment, and disposal of hazardous and nonhazardous solid waste. RCRA was amended and expanded in 1984 by the Hazardous and Solid Waste Act. "Solid waste" is broadly defined in RCRA to include most all waste forms, including liquids and compressed gases. RCRA provides for the classification of waste as hazardous or nonhazardous based either on characteristics, source lists, or identifying criteria. Biomass 
liquefaction (or any type of biomass conversion) is not found on the source lists, therefore the wastes could not be ruled hazardous on that basis. Some of the characteristics may apply to biomass liquefaction wastewaters in some cases. The characteristics include ignitaoility (flash point $<60 \mathrm{C}$ ), corrosivity $(\mathrm{Ph}<2$ or $\mathrm{Ph}>12.5$ or steel corrosion $>0.25 \mathrm{inch} / \mathrm{yr} @ 55 \mathrm{C}$ ), reactivity (numerous e'samples which don't apply), or TCLP (toxicity characteristic leaching procedure). TCLP toxicity includes a list of numerous elements and compounds with concentration limits. The concentration can apply to the extract of a solid waste (using the standard TCLP method) or the concentration of the liquid waste itself. The components of interest in biomass liquefaction in the current (March 1990) TCLP list are given in Table 4.

TABLE 4

Partial TCLP list of maximum concentration of contaminants

\begin{tabular}{llll}
\hline $\begin{array}{l}\text { Dangerous } \\
\text { Waste } \\
\text { Number }\end{array}$ & Contaminant & $\begin{array}{l}\text { (Chemical } \\
\text { Abstract } \\
\text { Services \#) }\end{array}$ & $\mathrm{mg} / \mathrm{L}$ \\
\hline D004 & Arsenic & $(7440-38-2)$ & 5.0 \\
D005 & Barium & $(7440-39-3)$ & 100.0 \\
D018 & Benzene & $(71-43-2)$ & 0.5 \\
D006 & Cadmium & $(7440-43-9)$ & 1.0 \\
D007 & Chromium & $(7440-47-3)$ & 5.0 \\
D023 & ortho-cresol & $(95-48-7)$ & 240.0 \\
D024 & meta-cresol & $(108-39-4)$ & 240.0 \\
D026 & para-cresol & $(106-44-5)$ & 240.0 \\
D026 & Cresol (total) & & 240.0 \\
D008 & Lead & $(7439-92-1)$ & 5.0 \\
D009 & Mercury & $(7439-97-6)$ & 0.2 \\
D035 & Methyl ethyl ketone & $(78-93-3)$ & 240.0 \\
D038 & Pyridine & $(110-86-1)$ & 5.0 \\
D010 & Selenium & $(7782-49-2)$ & 1.0 \\
D011 & Silver & $(7440-2.2-4)$ & 5.0
\end{tabular}

The balance of the TCLP list includes nitro-aromatics, chlorinated hydrocarbons, and pesticides. None of these are likely to be found in biomass liquefaction wastewaters. Phenol is a curious omission from this list in light of the inclusion of cresols.

The more general criteria for identifying hazardous wastes may also apply. These criteria include human toxicity at low doses or animal toxicity if human data are not available. The animal levels are oral LD50 (rat) at $<50 \mathrm{mg} / \mathrm{kg}$, inhalation LD50 (rat) at $<2 \mathrm{mg} / \mathrm{L}$, or dermal LD50 (rabbit) at $<200 \mathrm{mg} / \mathrm{kg}$. Secondly, the waste may contain any of a long list of components that may be present in such concentration as to be hazardous or could degrade to a hazardous component. Consideration is given to the amount and disposal method for the waste and the impact on the environment, as well as evaluations from other governmental agencies 
or regulatory programs. Components likely to be found in biomass liquefaction effluent are in Table 5, a subset of the TCLP list.

TABLE 5

List of Hazardous Constituents in Biomass Liquefaction Wastewaters

\begin{tabular}{|c|c|c|}
\hline $\begin{array}{l}\text { Dangerous } \\
\text { Waste } \\
\text { Number }\end{array}$ & Contaminant & $\begin{array}{l}\text { Chemical } \\
\text { Abstract } \\
\text { Number }\end{array}$ \\
\hline P005 & 2-properiol (allyl alcohol) & $107-18-6$ \\
\hline P054 & Aziridine (ethylenimine) & $151-56-4$ \\
\hline P067 & 2-methylaziridine & $75-55-8$ \\
\hline P003 & 2-propenal (acrolein) & $107-02-8$ \\
\hline P005 & 2-propen-1-ol (allyl alcohol) & $107-18-6$ \\
\hline U001 & Acetaldehyde (ethanal) & $75-07-0$ \\
\hline $\mathrm{U} 112$ & Ethyl acetate & $141-78-6$ \\
\hline U002 & Acetone & $67-64-1$ \\
\hline U004 & Acetophenone & $98-86-2$ \\
\hline U008 & Acrylic acid (2-propenoic acid) & $79-10-7$ \\
\hline $\mathrm{U} 113$ & Ethylacrylate & $180-88-5$ \\
\hline $\mathrm{U} 118$ & Ethyl methacrylate & $97-63-2$ \\
\hline U162 & Methyl methacrylate & $80-62-6$ \\
\hline U012 & Aniline & $62-53-3$ \\
\hline U018 & Benz(a)anthracene & $56-55-3$ \\
\hline U094 & 7,12-dimethylbenz(a)anthracene & $57-97-6$ \\
\hline U019 & Benzene & $71-43-2$ \\
\hline U239 & Dimethylbenzene (xylene) & $1330-20-7$ \\
\hline U201 & 1,3-benzenediol (resorcinol) & $108-46-3$ \\
\hline $\mathrm{U} 220$ & Methylbenzene (toluene) & $108-88-3$ \\
\hline U055 & 1-methylethylbenzene (cumene) & $98-82-8$ \\
\hline U197 & Quinone & $106-51-4$ \\
\hline U031 & 1-butanol & $71-36-3$ \\
\hline U159 & 2-butanone (methylethylketone) & $78-93-3$ \\
\hline U053 & 2-butenal (crotonaldehyde) & $4170-30-3$ \\
\hline U050 & Chrysene & $218-01-9$ \\
\hline U051 & Creosote & $\cdots$ \\
\hline U052 & C.esol (cresylic acid) & $1319-77-3$ \\
\hline U056 & Cyclohexane & $110-82-7$ \\
\hline U057 & Cyclohexanone & $108-94-1$ \\
\hline U094 & 7,12-dimethylbenz(a)anthracene & $57-97-6$ \\
\hline U101 & 2,4-dimethylphenol (2,4-xylenol) & $105-67-9$ \\
\hline U120 & Fluoranthene & $206-44-0$ \\
\hline $\mathrm{U} 12.2$ & Formaldehyde & $50-00-0$ \\
\hline U123 & Formic acid & $64-18-6$ \\
\hline U124 & Firan & $110-00-9$ \\
\hline Ũरis & 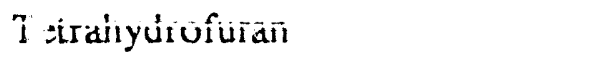 & $100-000$ \\
\hline $\mathrm{U} 125$ & Furfural & $98-01-1$ \\
\hline
\end{tabular}


TABLE 5 (cont.)

List of Hazardous Constituents in Biomass Liquefaction Wastewaters

\begin{tabular}{lll}
\hline $\begin{array}{l}\text { Dangerous } \\
\text { Waste } \\
\text { Number }\end{array}$ & Contaminant & $\begin{array}{l}\text { Chemical } \\
\text { Abstract } \\
\text { Number }\end{array}$ \\
\hline U140 & 2-methyl-propanol (isobutyl alcohol) & $78-83-1$ \\
U154 & Methanol & $67-56-1$ \\
U161 & 4-methyl-2-pentanone (methyl isobutyl ketone) & $108-10-1$ \\
U165 & Naphthalene & $91-20-3$ \\
U166 & 1,4-naphthalenedione (naphthoquinone) & $130-15-4$ \\
U188 & Phenol & $108-95-2$ \\
U196 & Pyridine & $110-86-1$ \\
U191 & Methylpyridine & $109-06-8$
\end{tabular}

This component list is apparentiy based on toxicity data in the literature. The specifics of why one component is listed and a similar component is not explained. Since this criteria basis for hazardous designation is a judgement call, similar components may be considered by the EPA in the designation process. The "P" numbered components at the top of the list are considered hazardous even at very low concentrations; the " $U$ " numbered components are considered hazardous only at higher concentrations.

Clean Water Act: The Clean Water Act was enacted to protect surface waters from point and non-point sources of pollutants. Under this act, all discharges of pollutants must be in compliance with a National Pollutant Discharge Elimination System (TPDES) permit that is issued by the EPA or the state, if EPA has delegated NPDES authority to the state. Two general sets of standards that may be applicable have been promulgated under the Clean Water Act: categorical standards and water quality standards. Categorical standards are applicable to various categories of industrial discharges. Water quality criteria are not promulgated but are published as a separate document that is updated periodically.

To be allowed to dispose of wastewater outside of a hazardous waste disposal site, either a NPDES permit must be obtained or the wastewater must be accepted into a POTW (publicly owned treatment works). To obtain a NPDES permit for a wastewater stream, the flow volume and contamination level must be defined. The level of contamination allowed is subject to negotiation. Gaining acceptance by a POTW is similarly based on negotiation. Potential exists for higher levels of discharge to be allowed into the POTW because of the dilution of the stream with other waste streams. The POTW operates under a permit similar to a NPDES permit and must meet certain contaminant levels in its effluent. The same EPA or state organization will issue either the NPDES permit or the POTW's permit.

Safe Drinking Water Act: The Safe Drinking Water Act (SDWA) was enacted in 1974 and amended in 1986. To protect public drinking water sources, EPA is required to develop mechanisms to control bacterial and chemical contaminants and to regulate the underground injection of contaminants into groundwater. The SWDA mandates the creation of primary and secondary standards to regulate the quaiity of water that is available to the public through community and non-community water 
systems. Primary standards protect public health by establishing maximum contaminant levels (MCL). MCLs are limits based on maximum contaminant level goals (MCLG), the levels at which public health will not be adversely affected. MCLs are set as close to the MCLGs as is technically feasible. Secondary standards, Secondary Maximum Contaminant Levels, protect public welfare by regulating the aesthetic qualities of water.

The MCLs currently in place apply only to a short list of inorganics and organic compounds. The inorganics are the metr.ls found in the TCLP list in Table 4 plus nitrate analysis. The organics are the pesticide chemicals from the TCLP list and a total trihalomethanes analysis. The MCLs are two orders of magnitude in concentration below the TCLP levels. If the wastewater from biomass liquefaction was found to be a nonhazardous waste under RCRA (or was cleaned up to that level) it could then be discharged if it niet the SDWA standards. A NPDES permit would be needed so that flow volume of the waste could be controlled.

This discussion is limited to the liquid effluents from biomass liquefaction. Not discussed here are the gas emissions, which will also be regulated. Gas emissions will include leakage from equipment. RCRA regulations also apply to the solid waste streams that might be produced in biomass liquefaction.

\section{CONCLUSIONS}

The broad range of processing conditions involved in direct biomass liquefaction lead to a variety of product properties. The aqueous byproduct streams have received limited analysis because priority has been placed on analysis of the complex organic liquid product. The range of organic contaminants carried in the aqueous byproducts directly correlates with the quantity and quality of contaminants in the liquid oil product. The data in the literature gives a general indication of the types and amounts of components expected in biomass liquefaction wastewater; however, the data is insufficient to prepare a general model that predicts the wastewater composition from any given liquefaction process. Therefore, further study will be needed on the wastewater from any specific biomass liquefaction process as the process is developed. Analysis must address both the organic contaminants and inorganic residues.

It is possible to avoid a separate aqueous byproduct phase in the case of the flash pyrolysis processes, which produce a highly oxygenated oil that includes the aqueous phase as a dissolved component. In these cases, care must be exercised to maintain the single phase by controlling the amount of water introduced into the process stream and by making a total product collection in a single step without separating an aqueous-rich stream. There is some disagreement as to the amount of water which will result in the formation of a separate water layer. More study is needed to define a model that considers the oil components and their source (feedstock and operating conditions) and can predict the amount of water that is soluble in the oil and the level of dissolved water required to separate a second aqueous-rich phase from the oil.

Much less is known about the aqueous byproduct streams produced in the upgrading of the biomass liquefaction products to turbine or engine fuels because much less research has been performed on these upgrading processes. In all the 
upgrading iechnologies the common factor is the removal of oxygen from the liquid product, which results in the separation of an aqueous byproduct phase. Again, depending on the chemical properties of the upgraded product, the aqueous byproduct can contain a range of organic contaminants. Further analysis is needed to better define the aqueous byproduct contaminants. These contaminants will include both the organics and catalyst residues.

In some process cases, it has been proposed that the aqueous stream has fuel value for the process and can be burned in an incinerator. No test data are available for such incineration systems based on biomass liquefaction wastewater. More compleie analysis of the aqueous byproducts may allow an educated guess as to the incineration properties of these materials, but test incineration of the streams would be mure convincing.

Treatment technologies need to be tesied with biomass liquefaction wastewaters. Potential systems include oxidation and catalytic reforming as well as biological treatment systems. Oxidation systems include conventional incineration, wet oxidation, or chemical oxidants, such as ozone or chlorine. The catalytic reforming is a new technology for pressurized conversion of organics in water to fuel gases. Biological treatment systems, such as aerobic or anaerobic digestion, should also be tested on biomass liquefaction wastewaters. All of these systems should be evaluated for potential use in biomass liquefaction wastewater treatment. Benchscale testing should be undertaken for those systems determined to be most applicable.

A major gap in the information on biomass liquefaction wastewater treatment is a full understanding of the regulatory environment that applies to the process. The wastewater treatment regulations themselves are still subject to much revision. Although this paper reviewed specifically the U.S. regulations, it is likely that regulations in other countries will also address these issues. It is apparent that certain chemicals produced in biomass liquefaction will be of concern to regulators. Since the implementation period and site for the biomass liquefaction process will have a strong impact on the wastewater requirements, it seems inappropriate to further limit development of the processes based on perceived regulations at some unknown future time and place. However, process developers should maintain an awareness of the regulatory environment as it might apply to them.

\section{ACKNOWLEDGMENT}

This paper was prepared at Pacific Northwest Laboratory* under Memorandum Purchase Order from the National Renewable Energy Laboratory (formerly the Solar Energy Research Institute). Preparation of this report was instigated by a request from the International Energy Agency, Bioenergy Conversion Wastewater Analysis and Treatment Activity Working Group (T7/A7). The author acknowledges the support of Ian Hunter, the Activity Leader, and Ralph Overend of NREL who provided the means of support for the effort.

*Operated for the U. S. Department of Energy by Battelle Memorial Institute under

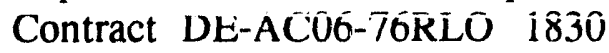




\section{REFERENCES}

1. Appell, H. R., Fu, Y. C., Friedman, S., Yavorsky, P. M. and Wender, I. Converting organic wastes to oil: A replenishable energy source. Report of Investigations 7560, Pittsburgh Energy Research Center, Pittsburgh, 1971.

Appell, H. R., Fu, Y. C., Illig, E. G., Steffgen, F. W., and Miller, R. D. Conversion of cellulosic wastes to oil. Report of Investigations 8013, Pittsburgh Energy Research Center, Pittsburgh, 1975.

2. Kaufman, J. A., and Weiss, A. H., Solid waste conversion: cellulose liquefaction. PB 239 509, National Technical Information Service, Springfield, Virginia, 1975.

3. Beckman, D., and Elliott, D. C., Comparisons of the yield and properties of the oil products from direct thermochemical biomass liquefaction processes. Can. Jour. Chem. Eng., 1985, 63(1), 99-104.

Flliott, D. C., Beckman, D., Bridgwater, A. V., Diebold, J. P., Gevert, S. B., and Solantausta, Y., Developments in direct thermochemical liquefaction of biomass: 1983-1990. Energy \& Fuels, 1991, 5, 399-410.

4. White, D. H. and Wolf, D., Advances in direct biomass liquefaction by the extruder-feeder method. In Research in Thermochemical Biomass Conversion, eds. A. V. Bridgwater and J. L. Kuester, Elsevier Science Publishers, LTD., Barking, England, 1988, pp. 827-842.

Björnbom, P. and Björnbom, E. Fuel, 1988, 67, 1589-1592.

Björnbom, E., Björnbom, P., and Karlsson, O. Fuel Process. Technol., 1988, 17, 263-276.

Boocock, D. G. B., Chowdhury, A., and Kosiak, L. Aspects of the steam liquefaction of poplar wood chips in a gravity fed reactor. In Research in Thermochemical Biomass Conversion, eds. A. V. Bridgwater and J. L. Kuester, Elsevier Science Publishers, LTD., Barking, England, 1988, pp. 843-853.

McKeough, P. and Johansson, A. Oil production by high-pressure thermal treatment of black liquors: process development studies. In Pyrolysis Oils from Biomass: Producing. Analyzing and Upgrading - ACS Symposium Series 376, eds., E. J. Soltes and T. A. Milne, American Chemical Society, Washington, DC, 1988, pp. 104-112.

Meier, D., and Faix, O. Production and analysis of oils obtained by catalytic hydroliquefaction of wood. In Research in Thermochemical Biomass Conversion, eds. A. V. Bridgwater and J. L. Kuester, Elsevier Science Publishers, LTD., Barking, England, 1988, pp. 804-815.

5. Kovac, R. J., Gorton, C. W., and O'Neil, D. J., In Thermochemical Conversion Program Annual Meeting, SERI/CP-231-3355. Solar Ei. :rgy Research Institute, Golden, Colorado, 1988, pp. 5-20. 
Scott, D. S. and Piskorz, J., Can. J. Chem. Eng., 1984, 62, 404-412.

Scott, D. S., Piskorz, J., Bergougnou, M. A., Graham, R., and Overend, R. P. Ind. Eng. Chem. Res., 1988, 27, 8-15.

Graham, R., Freel, B. A., and Bergougnou, M. A., The production of pyrolytic liquids, gas, and char from wood and cellulose by fast pyrolysis. In Resu.3rch in Thermochemical Biomass Conversion, eds. A. V. Bridgwater and J. L. Kuester, Elsevier Science Publishers, LTD., Barking, England, 1988, pp. 629-641.

6. Diebold, J. P. and Power, A. J., Engineering aspects of the vortex pyrolysis reactor to produce primary pyrolysis oil vapors for use in resins and adhesives. In Research in Thermochemical Biomass Conversion, eds. A. V. Bridgwater and J. L. Kuester, Elsevier Science Publishers, LTD., Barking, England, 1988, pp. 609-628.

7. Antonelli, L., In Energy from Biomass 4. Proceedings of the 'Third Contractors' Mleeting, eds. G. Grassi, D. Pirrwitz, and H. Zibetti, Elsevier Applied Science, London, 1989, p.531.

8. Roy, C., deCaumia, B., and Pakdel, H., Preliminary feasibility study of the biomass vacuum pyrolysis process. In Research in Thermochemical Biomass Conversion, eds. A. V. Bridgwater and J. L. Kuester, Elsevier Science Publishers, LTD., Barking, England, 1988, pp. 585-596.

9. Elliott, D. C. and Schiefelbein, G. F., Liquid hydrocarbon fuels from biomass," Amer. Chem. Soc. Fuel Chem. Preprts., 1989, 34(4), 1160-1166.

10. Elliott, D. C., and Baker, E. G., Catalytic hydrotreating of biomass liquefaction products to produce hydrocarbon fuels: Interim Report. PNL-5844, Pacific Northwest Laboratory, Richland, Washington, 1986.

Baker, E. G., and Elliott, D. C., Catalytic hydrotreating of biomass-derived oils. In Pyrolysis Oils from Biomass: Producing, Analyzing and Upgrading - ACS Symposium Series 376, eds. E. J. Soltes and T. A. Milne, American Chemical Society, Washington, DC, 1988, pp. 228-240.

Gevert, S. B., Upgrading of Directly Liquefied Biomass to Transportation Fuels. Chalmers University of Technology, Göteborg, Sweden, 1987.

Soltes, E. J., and Lin, S-C. K., Hydroprocessing of biomass tars for liquid engine fuels. In Progress in Biomass Conversion, Vol. 5, eds. D. A. Tillman and E. C. Jahn, Academic Press, New York, 1984, p. 1.

Churin, E., Maggi, R., Grange, P., and Delmon, B., Characterization and upgrading of a bio-oil produced by pyrolysis of biomass, In Research in Thermochemical Biomass Conversion, eds. A. V. Bridgwater and J. L. Kuester, Elsevier Science Publishers, LTD., Barking, England, 1988, pp. 896-909.

11. Elliott, D. C., and Baker, E. G., Catalytic hydrotreating processes for upgrading biocrude oils. In Thermochemical Conversion Program Annual Meeting,

SERI/CP-231-3355, National Renewable Energy Laboratory, Golden, Colorado, 1988, pp. 45-56. 
Gevert, S. B., and Otterstedt, J-E., Upgrading of directly liquefied biomass to transportation fuels - catalytic cracking. Biomass, 1987, 14, 173-183.

12. Elliott, D. C., and Baker, E. G., Hydrotreating biomass liquids to produce hydrocarbon fuels, In Energy from Biomass and Wastes X, ed. D. L. Klass, Institute of Gas Technology, Chicago, 1987, pp. 765-784.

Elliott, D. C., and Baker, E. G., Process for upgrading biomass pyrolyzates." U.S. Patent \#4,795,841, issued January 3, 1989.

13. Baker, E. G., and Elliott, D. C., Catalytic upgrading of biomass pyrolysis oils. In Research in Thermochemical Biomass Conversion, eds. A. V. Bridgwater and J. L. Kuester, Elsevier Science Publishers, LTD., Barking, England, 1988, pp. 883-895.

14. Scahill, J., Diebold, J. P., and Power, A., Engineering aspects of upgrading pyrolysis oil using zeolites. In Research in Thermochemical Biomass Conversion, eds. A. V. Bridgwater and J. L. Kuester, Elsevier Science Publishers, LTD., Barking, England, 1988, pp. 927-940.

15. McKinley, J., Biomass Liquefaction: Centralized Analysis. Final Report, Project No. 4-03-837, BC Research, Vancouver, B.C., Canada, 1989, pg. 127.

16. Appell, H. R., Wender, I., and Miller, R. D. Conversion of Urban Refuse to Oil. TP Report \#25, U.S. Bureau of Mines, Pittsburgh, Pennsylvania, 1970.

17. Rust International Corporation, Final Report: An Investigation of Liquefaction of Wood at the Biomass Liquefaction Facility Albany, Oregon. PNL-5114, Pacific Northwest Laboratory, Richland, Washington, 1982.

18. Elliott, D. C., Bench-Scale Research in Biomass Liquefaction in Support of the Albany, Oregon, Experimental Facility. Quarterly Technical Status Report, December 31, 1979 - March 30, 1980. Pacific Northwest Laboratory, Richland, Washington, 1980.

19. Elliott, D. C., Description and utilization of product from direct liquefaction of biomass. In Biotechnol. and Bioeng. Symp. No. 11, 1981, pp. 187-198.

20. Davis, H. G., Kloden, D. J., and Schaleger, L. L., Chemistry and stoichiometry of wood liquefaction. In Biotechnol and Bioeng. Symp. No. 11, 1981, pp. 151169.

21. Eager, R. L., Mathews, J. F., Pepper, J. M., and Zohdi, H., Studies on the products resulting from the conversion of aspen poplar to an oil. Can. J. Chem., 1981, 59, 2191-2198.

22. Boocock, D. G. B., Mackay, D., and Lee, P., Wood liquefaction: extended batch reactions using raney nickel catalyst. Can. J. Chem. Eng., 1982, 60, 802808. 
23. Boocock, D. G. B. and Sherman, K. M., Further aspects of powdered poplar wood liquefaction by aqueous pyrolysis. Can. J. Chem. Eng., 1985, 63, 627-633.

Boocock, D. G. B., Allen, S. G., Chowdhury, A., and Fruchtl, R., Producing, evaluating, and upgrading oils from steam liquefaction of poplar chips. In: Pyrolysis Oils from Biomass: Producing Analyzing and Upolading - ACS Symposium Series 376, eds. E. J. Soltes and T. A. Milne, American Chemical Society, Washington, DC, 1988, pp. 92-103.

24. Björnbom, E., Olsson, B., and Karlsson, O., Thermochemical refining of raw peat prior to liquefaction. Fuel, 1986, 65, 1051-1056.

25. Elliott, D. C., Analysis and Upgrading of Biomass Liquefaction Products, Final Report. Volume 4, IEA Co-Operative Project D-1, Biomass Liquefaction Test Facility Project. DOE/NBM-1062(vol.4), National Technical Information Service, Springfield, Virginia, 1984.

Piskorz, J., Majerski, P., and Scott, D. S., Liquid fuels from canadian peat by the waterloo fast pyrolysis process. Can. J. Chem. Eng., 1990, 68, 465-472.

26. Scahill, J. and Diebold, J. P., Adaptation of the seri vortex reactor for rdf pyrolysis. In Thermochemical Conversion Prngram Annual Meeting June 21 22, 1988. SERI/CP-231-3355, National Renewable Energy Laboratory, Golden, Colorado, 1988.

27. Piskorz, J., Radlein, D. S., Scott, D. S., and Czernik, S., Liquid products from the fast pyrolysis of wood and cellulose. In Research in Thermochemical Biomass Conversion, eds. A. V. Bridgwater and J. L. Kuester, Elsevier Science Publishers, LTD., Barking, England, 1988, pp. 557-571.

28. Diebold, J.P. and Scahill, J., Production of primary pyrolysis oils in a vortex reactor. In Pyrolysis Oils from Biomass: Producing, Analyzing and Upgrading ACS Symposium Series 376, eds. E. J. Soltes and T. A. Milne, American Chemical Society, Washington, DC, 1988, pp. 31-40.

29. Roy, C., Lemieux, R., deCaumia, B., and Blanchette, D., Processing of wood chips in a semicontinuous multiple-hearth vacuum-pyrolysis reactor. In Pyrolysis Oils from Biomass: Producing, Analyzing and Upgrading - ACS Symposium Series 376, eds. E. J. Soltes and T. A. Milne, American Chemical Society, Washington, DC, 1988, pp. 16-30.

30. Pakdel, H. and Roy, C., Production and characterization of carboxylic acids from wood, part i: low molecular weight carboxylic acids." Biomass, 1987, 13, 155-171. 

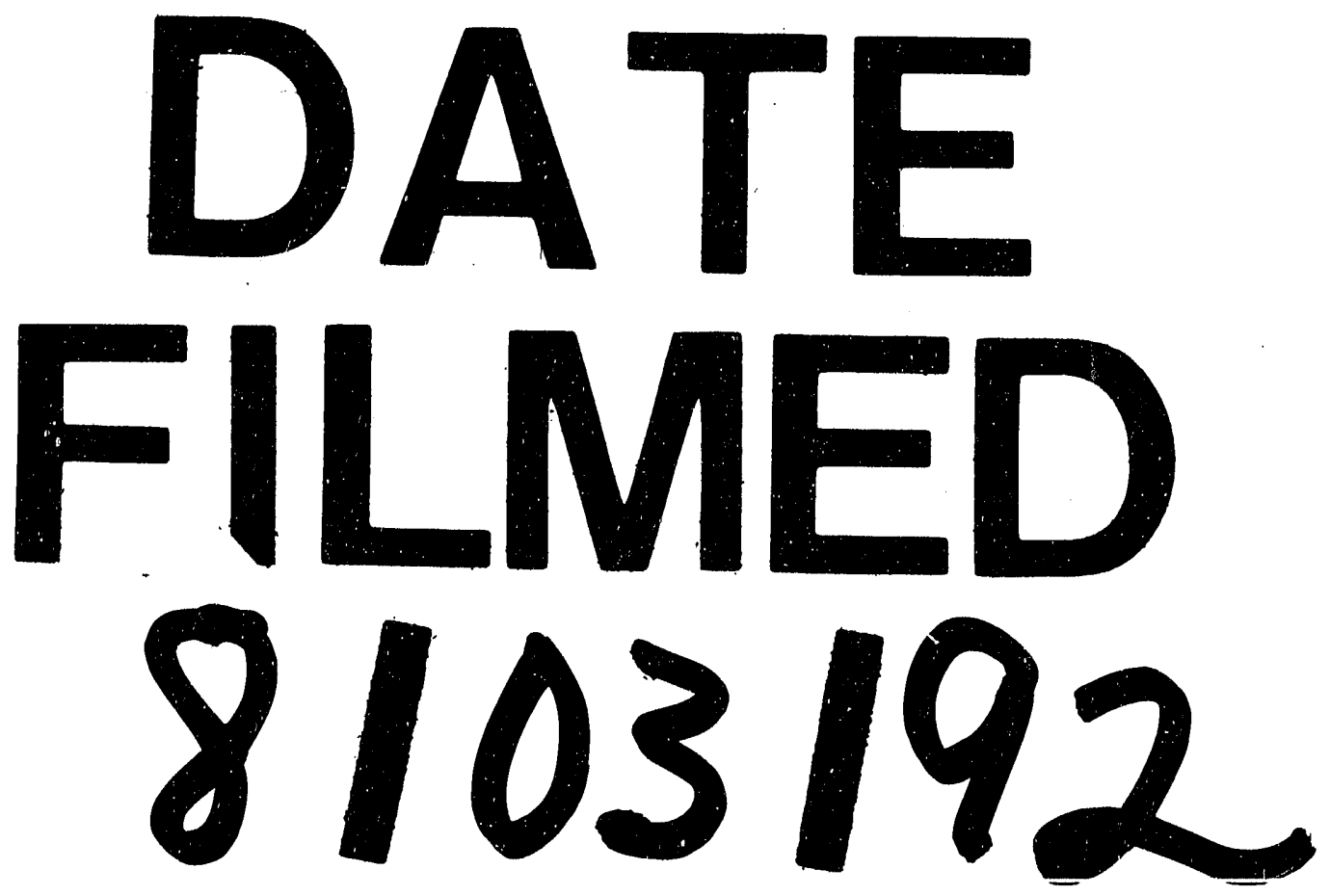
